\title{
LINKING MACRO AND REGIONAL LEVEL ECONOMIC FORECASTS: ALTERNATIVE REGIONAL GROWTH PATHS IN HUNGARY
}

\author{
Zsuzsanna ZSIBÓK ${ }^{\mathrm{a}}$ \\ ${ }^{a}$ HAS CERS Institute for Regional Studies, 22 Papnövelde str., H-7621 Pécs, Hungary, e-mail: \\ zsibok@rkk.hu
}

Cite this article: Zsibók, Z. (2018). Linking macro and regional level economic forecasts: Alternative regional growth paths in Hungary. Deturope, 10(3), 120-142.

\begin{abstract}
Economic development at the national level is often accompanied by territorial divergence at sub-national levels, which phenomenon became even more noticeable during and after the global financial and economic crisis. Current development policy have to face the well-known equity versus efficiency challenge to sustain the prosperity of the most advanced regions and, at the same time, to tackle the divergence between advanced and lagging regions. For this reason, a comprehensive knowledge is necessary about the long-run, interdependent dynamics of national and regional level growth. Our research contributes to this knowledge through studying alternative growth paths for Hungary in a comparative framework. We focus on the methods that apply a regionalisation procedure in order to downscale national level economic forecasts to the regional level.
\end{abstract}

Keywords: Regional development, Regional forecasting, Economic growth

\section{INTRODUCTION}

Economic development at the national level is often accompanied by territorial divergence at sub-national levels, which phenomenon became even more noticeable during and after the global financial and economic crisis. Current development policy have to face a double challenge: first, to sustain the prosperity of the most advanced regions as the fundamental motors of growth, and, second, to tackle the divergence between advanced and lagging regions that becomes not only economically inefficient, but also socially and politically dangerous (Iammarino et al., 2017). For this reason, a comprehensive knowledge is necessary about the long-run, interdependent dynamics of national and regional level growth. Our research contributes to this knowledge through comparing alternative regional growth paths which exhibit convergence or divergence. We focus on the methods that apply a regionalisation procedure in order to downscale national level economic forecasts to the regional level. The practice of "regionalisation" or regional downscaling intends to translate 
information available at a coarse geographical resolution (e.g. the national level) to a finer geographical scale (e.g. the regional level).

There are two basic approaches to producing regional-level economic forecasts. Bottom-up models are full-fledged regional models, specified in a standard way with well-established interregional feedback mechanisms (Magnani and Valin, 2009). They are also called generative models, since the national growth rate of the economy is the weighted sum of the regional growth rates, that is, the causal relationship runs from the regional level to the national level. The major drawback to this approach is the great data requirement (subject to availability problems), and the size of the model when working with a large number of regions and sectors. This article focuses on the other type of methods, which is called topdown or distributive approach. These "satellite" models forecast regional growth (and employment etc.) given the forecast of the national variables obtained from macro models. In other words, these methods allocate regional growth across the regions in a competitive manner according to a certain, e.g. statistical, rule (as described later). Magnani and Valin (2009) states that although top-down (CGE, computable general equilibrium) models neglect the general equilibrium linkages at the regional level, they are much more reliable because they are based on robust data and do not need strong assumptions concerning the values of the behavioural parameters (such as elasticities). The top-down approach somewhat reflects the "spatial zero-sum game" view ${ }^{13}$ of economic growth: in the case of the top-down methods, the causal relationship runs from the national level to the regional level, and no individual region is able to have any impact on aggregate growth. Thus, top-down methods apply an ex post approach, while bottom-up methods use an ex ante approach (for a detailed comparison, see Chizzolini, 2008). At the final step, a proportional rescaling is needed to ensure ex post, that the regional values sum up to the national aggregates. The top-down approach can be regarded as "regional downscaling" which is wide spread in the field of integrated assessment modelling which considers social and economic factors in environmental modelling (see e.g. van Vuuren et al., 2007). In this field, long-run forecasts are most often produced at the global scale or for world regions, and there is a need to downscale them to, e.g. the national level.

According to Capello et al. (2017a), the last methodological advances are linked to the simultaneous introduction of a top-down and a bottom-up approach, which makes it possible for national growth to influence regional growth and vice versa. This means that these mixed

\footnotetext{
${ }^{13}$ This concept was used by Martin (2015) who criticized those approaches that think about economic growth as a "spatial zero-sum game", assuming that there is some fixed amount of economic growth or activity that can be distributed across the national space economy.
} 
or hybrid models are formalized as cumulative and generative at the same time, as illustrated by the MASST3 model (Capello et al., 2017b), the MultiREG-SpVAR approach (Ramajo et al., 2017) and the GMR model (Varga, 2017).

The aim of this research is to compare the results of different regional-level forecasting methods regarding the period between 2020 and 2050 at the NUTS 3 level in Hungary with respect to the gross domestic product (GDP). The existing, state-of-the-art, bottom-up approaches are multi-sectoral, multi-regional structural models with quite large resource requirements. I intend to present the results of some more simplistic methods with a top-down approach, keeping in mind that there may be a trade-off between the resource requirement and the reliability of the model results.

The second section describes the most relevant theoretical and policy frameworks of our research. Then, a short analysis of past trends and a few projection methods will be introduced. The empirical results will be presented in the fourth section. The last section concludes by suggesting that growing regional inequalities are predicted by almost all scenarios, therefore, regional policy has to face significant challenges.

\section{THEORETICAL AND POLICY APPROACHES}

When applying the top-down approach in regional economic forecasting, some assumptions have to be made with respect to the nature of the co-movement between national level and regional level economic variables. Regional development theories provide useful guidance with respect to this question, and they are also helpful in developing alternative scenarios of the dynamics of regional inequalities. Most current models build upon Krugman's New Economic Geography describing micro-founded economic models of regional growth based on firms' increasing returns, as well as urban economics which emphasises the advantages that stem from the density of activity and human capital within cities (see e.g. Glaeser, 2011). This stream of literature points towards the notion that national economic development implies increasing regional divergence, that is, there is a trade-off between national efficiency and spatial equity, because spatial agglomeration may actually raise aggregate national growth. As a consequence, regional imbalance may benefit national growth, and policies that seek to reduce regional economic inequalities may be nationally inefficient (see Martin, 2008 for a detailed analysis). More sophisticated descriptions of the evolution of regional inequalities can accommodate both convergence and divergence models, such as Williamson's (1965) inverted-U model. 
Advocates of the NEG-based efficiency argument propose that resources spent on the most developed, central regions have positive spillover effects on other neighbouring, or even more distant regions (see World Bank, 2009 and Leunig, 2008). In this line of reasoning, the best way of reducing disparities is the fostering of economic integration between high-growth and lagging regions (Gill 2010, OECD 2011). Nevertheless, empirical studies are not equivocal to verify this assumption, and some of them found firm evidence against this position (e.g. McCann, 2016 in the UK, see Zsibók, 2017).

The equity versus efficiency dilemma poses a challenge to regional policy makers (as discussed in Martin, 2008). Enyedi (2010) presents that the current key sectors of the economy - knowledge-based economy and creative industry - tend to cluster in the largest, developed cities. In order to achieve an overall national catching-up, the strengthening of the international competitiveness of these metropolitan areas within the country is needed. At the same time, in the absence of regional policy intervention, these processes lead to the continuous decline of the regions that do not have such dynamic sectors. ${ }^{14}$

Several recent empirical works suggest that the proposed trade-off may not exist (Gardiner et al., 2011). Alternative, place-based theories emphasize that there is no automatic convergence between advanced and backward places, therefore national growth can be maximised through exploiting capacities in all regions, both developed and lagging. Preferably, policy interventions are able to differentiate between developed and lagging areas (Iammarino et al., 2017, Varga, 2017, Lennert, Csatári, Farkas, \& Mezőszentgyörgyi, 2015). Place-based policies, as proposed by Barca et al. (2012) take into consideration the variety of local knowledge, institutional capabilities and competences in different geographical locations which may affect the potential returns of local policy interventions. Thereby they adopt a bottom-up, generative approach emphasising the importance of the process of entrepreneurial discovery and other supply-side factors (Capello et al., 2017a).

Martin (2008) emphasises that regional economists should investigate both theoretically and empirically the conditions under which the promotion of economic growth within all regions of a country could reduce inter-regional inequality and increase overall national growth simultaneously. This could happen within the frameworks of the NEG models or outside them and should be supported by comprehensive empirical evidence.

In sum, national growth can occur together with either regional convergence or regional divergence, and the actual dynamics of regional inequalities is not only influenced by market forces, but also, to a large extent, by national policies (Hadjimichalis and Hudson, 2014). For this reason, the projected national and regional pathways in the next sections show a range of

\footnotetext{
${ }^{14}$ See Egyed (2016) for the analysis of this question in a French context.
} 
alternatives which all have to be considered by national policies in order to orient effective interventions for long-run socio-economic development.

\section{PAST TRENDS AND EMPIRICAL FORECASTING METHODS}

There are only a few examples that deal with the forecasting of regional inequalities in Hungary. The most notable is the GMR-Hungary model that is centred on policy impact assessment (Varga, 2017), and Jakobi (2004) that forecasted the dynamics of the main indicators of territorial inequalities in Hungary. Some long-run macroeconomic forecasts are available on the national level based on the ECO-TREND model (Keresztély, 2004), and an experimental, regional downscaling exercise was presented by Zsibók and Sebestyén (2017) at the NUTS 3 level. In terms of the methodological alternatives, there are significant differences between the short-, medium and long-run forecasts, and, of course, the longer the forecast horizon, the more difficulties arise (Fratesi, 2009, Lehmann and Wohlrabe, 2014). The simplest statistical procedure to downscale national-level forecasts is the linearproportional disaggregation which assumes constant regional shares within the national economy through the whole forecasting horizon, where the constant shares are computed on historical data. This method is often used in integrated assessment models (see Gaffin et al., 2004) or in some CGE models, such as ORANI and MONASH-RES (see Haddad, 2009, Dixon et al., 1982 and Parmenter and Welsh, 2001). Since this assumption excludes the possibility of spatial convergence or divergence, it can be used as a benchmark forecast. Additional scenarios may exhibit convergence/divergence according to, for example, a betaconvergence equation, in which the levels of GDP per capita in a given year are negatively correlated with the subsequent growth rates. More sophisticated regionalisation methods can range from (spatial) vector autoregression and spatial dynamic panel models (e.g. Beenstock and Felsenstein, 2007, Baltagi et al., 2014, Elhorst, 2009) through dynamic factor models (Stock and Watson, 2002, Owyang et al., 2009) and shift-share techniques (Hoorelbeke et al., 2007, Mayor et al., 2007 and Koops and Muskens, 2005) to more sophisticated, multiregional model-based forecasting procedures (Magnani and Valin, 2009). From this menu, in this article we consider a simple statistical trend approach which is extended by a decomposition exercise and convergence functions.

The centre of interest in this paper is the variable of $\mathrm{GDP}^{15}$, which, in the second stage of our analysis will be extended with demographic and employment projections. The basis of our

\footnotetext{
${ }^{15}$ Spatial economic inequalities are often studied with per capita GDP, however, changes in the per capita GDP reflect not only the economic development, but also the demographic changes which may distort the picture.
} 
forecasting exercise is, on one hand, the past evolution of NUTS 3 level GDP, and on the other hand, the existing national-level forecasts which will be regionalised. As a starting point, we consider the methods presented by Batista e Silva et al. (2016) with some modifications. In that work, the authors regionalise the country-level macroeconomic forecasts of the 2015 Ageing Report (European Commission, 2015, hereafter AR 2015) following two different assumptions: trend approach and convergence approach. Other national level forecasts are also available from international organisations; the reason for opting for the use of the AR 2015 projections ${ }^{16}$ is that it is based on EuroStat data, prepared by the European Commission, available on a 5-years' interval, and is exempt from projecting extreme low or high growth rates.

Table 1 Projected potential GDP growth rate at the national level in Hungary and in the EU $(\%)$

\begin{tabular}{lrrrrrrr}
\hline & 2020 & 2025 & 2030 & 2035 & 2040 & 2045 & 2050 \\
\hline Hungary & 1.94 & 2.14 & 1.99 & 1.50 & 1.18 & 1.32 & 1.38 \\
EU-28 & 1.43 & 1.35 & 1.40 & 1.54 & 1.43 & 1.42 & 1.42 \\
\hline
\end{tabular}

Source: own elaboration based on European Commission (2015)

The projections of the AR 2015 assume a catching-up process until the mid-2030s, which applies to those member states that are below the EU-28 average GDP level. This catching-up is driven by the above-average growth of total factor productivity and capital deepening ${ }^{17}$.

With respect to socio-economic processes at the regional level in Hungary, comparable historical data are available between 2000 and 2016 (2015 for employment data). These data indicate persistent regional inequalities with respect to the GDP. The global financial and economic crisis caused a hysteretic ${ }^{18}$ effect on the regional growth paths in Hungary: the growth in the most developed, capital region (Budapest and Pest county) started to slow down, while the regions near the core areas and the Austrian border started to develop more rapidly. These spatial processes and their possible underlying factors are analysed by Lengyel and Varga (2018) and Lengyel and Kotosz (2018) in detail.

\footnotetext{
${ }^{16}$ Updated projections are available from the end of May 2018 (The 2018 Ageing Report: Economic and Budgetary Projections for the EU Member States (2016-2070)), which provides projections on a 10 years' interval between 2020 and 2070 . We prefer the 2015 edition, since the time interval of the projections is 5 years and the projection period is between 2020 and 2060 which seems more certain than a period of more than a half century. Anyway, the period of our demographic projections ends in 2050.

17 Capital deepening is the growth in capital per labour input, e.g. hours worked, number of employees (European Commission, 2015).

${ }^{18}$ Hysteresis occurs when a temporary shock has a permanent effect on the steady state of a dynamic system (the interpretation of the concept in the context of regional economic processes is provided by Martin, 2011).
} 
Table 2 Per capita GDP (in purchasing power standards) in Hungary at the NUTS 3 level, $\mathrm{EU}-28=100$

\begin{tabular}{lccccc}
\hline NUTS 3 region & 2000 & 2004 & 2008 & 2012 & 2016 \\
\hline Bács-Kiskun & 37 & 42 & 42 & 46 & 51 \\
Baranya & 40 & 44 & 44 & 43 & 44 \\
Békés & 36 & 38 & 37 & 38 & 40 \\
Borsod-Abaúj-Zemplén & 34 & 40 & 40 & 40 & 47 \\
Budapest & 105 & 127 & 138 & 143 & 136 \\
Csongrád & 44 & 47 & 46 & 49 & 51 \\
Fejér & 61 & 59 & 59 & 61 & 70 \\
Győr-Moson-Sopron & 68 & 69 & 70 & 75 & 92 \\
Hajdú-Bihar & 39 & 47 & 44 & 49 & 47 \\
Heves & 37 & 44 & 44 & 43 & 49 \\
Jász-Nagykun-Szolnok & 35 & 39 & 40 & 42 & 44 \\
Komárom-Esztergom & 43 & 67 & 66 & 66 & 70 \\
Nógrád & 29 & 33 & 29 & 29 & 29 \\
Pest & 40 & 54 & 54 & 54 & 54 \\
Somogy & 36 & 41 & 39 & 42 & 41 \\
Szabolcs-Szatmár-Bereg & 30 & 35 & 33 & 36 & 38 \\
Tolna & 43 & 42 & 44 & 51 & 50 \\
Vas & 58 & 60 & 54 & 61 & 67 \\
Veszprém & 44 & 47 & 46 & 47 & 51 \\
Zala & 45 & 56 & 52 & 56 & 51 \\
\hline Hungary & 52 & 61 & 63 & 66 & 67 \\
\hline own elaboration based on EuroStat data & & & &
\end{tabular}

Source: own elaboration based on EuroStat data

Table 3 Average annual GDP growth rate in Hungary at the NUTS 3 level (measured at constant, 2005 prices), in percentages

\begin{tabular}{|c|c|c|c|c|c|}
\hline NUTS 3 region & $\begin{array}{l}2000- \\
2016\end{array}$ & $\begin{array}{l}2010- \\
2016\end{array}$ & NUTS 3 region & $\begin{array}{c}2000- \\
2016\end{array}$ & $\begin{array}{l}2010- \\
2016\end{array}$ \\
\hline Bács-Kiskun & 2.27 & 3.65 & Jász-Nagykun-Szolnok & 1.47 & 1.03 \\
\hline Baranya & 0.64 & 0.13 & Komárom-Esztergom & 3.62 & 2.18 \\
\hline Békés & 0.51 & 2.10 & Nógrád & -0.12 & 0.36 \\
\hline Borsod-Abaúj-Zemplén & 2.11 & 3.36 & Pest & 3.70 & 1.63 \\
\hline Budapest & 2.26 & 0.70 & Somogy & 1.00 & 1.07 \\
\hline Csongrád & 1.22 & 1.47 & Szabolcs-Szatmár-Bereg & 1.85 & 2.75 \\
\hline Fejér & 1.64 & 4.85 & Tolna & 0.90 & 1.03 \\
\hline Györ-Moson-Sopron & 3.07 & 6.03 & Vas & 1.37 & 4.31 \\
\hline Hajdú-Bihar & 1.74 & 1.14 & Veszprém & 1.07 & 2.77 \\
\hline Heves & 1.82 & 1.95 & Zala & 1.03 & 0.31 \\
\hline Hungary & 2.03 & 1.79 & & & \\
\hline
\end{tabular}

Source: own elaboration based on HCSO and National Bank of Hungary (NBH) data

The above presented past regional level and projected national level growth rates will provide the basis of our projections. 


\section{PROJECTED GROWTH PATHS IN HUNGARY AT THE NUTS 3 LEVEL}

\section{Benchmark projections}

Our GDP-projections will be prepared in two stages. In the first stage, we directly extrapolate past trends and use these as benchmark projections, then, in the next stage, we apply a decomposition exercise. In the next paragraphs we analyse the possible future NUTS 3 level GDP paths assuming that past trends continue. This trend approach can be interpreted in four alternative ways (see Batista e Silva et al., 2016 for the first three ones):

Assumption 1) regional growth rates remain constant at their historical levels:

$g_{i, t+n}^{Y}=g_{i, t B}^{Y}$

where superscript $Y$ denotes GDP, hence, $g_{i, t+n}^{Y}$ is the growth rate of GDP in region $i(i=1$ to 20 ) in period $t+n, g_{i, t B}^{Y}$ is the average past growth rate in the base period (2000 to 2016);

Assumption 2) regional growth rates equal the projected national level growth rate through the projection horizon (assuming constant spatial structure):

$g_{i, t+n}^{Y}=g_{H U, t+n}^{Y}$

where $g_{H U, t+n}^{Y}$ is the projected national level GDP growth rate in period $t+n$;

Assumption 3) regional growth rates gradually converge from their past levels towards the common, projected national growth rate:

$g_{i, t+n}^{Y}=w_{H U} * g_{H U, t+n}^{Y}+w_{r e g} * g_{i, t B}^{Y}$

where $w_{H U}$ and $w_{\text {reg }}$ are the weights assigned to the projected national growth rate and the past regional average growth rates, respectively (see Tab. 4 below);

Assumption 4) regional growth rates follow the projected national growth rate, but with a constant shift which shift is computed on the basis of the past deviation from the national growth rates:

$g_{i, t+n}^{Y}=g_{H U, t+n}^{Y}+\left(g_{H U, t B}^{Y}-g_{i, t B}^{Y}\right)$

where $g_{H U, t B}^{Y}$ is the average past national growth rate in the base period (2000 to 2016).

The first assumption uses past regional growth rates which continue in the future, for this reason, this may lead to large spatial divergence. The fourth one is similar to this, because it assumes that the deviation of the regional growth rates from the national rate remains constant. On the contrary, the second assumption implies that no spatial convergence or divergence will occur in the future, and it "freezes" spatial inequalities at their historical average level. It can be regarded as a "cautious", benchmark projection, since it says nothing about the future trends of the factors that influence spatial inequalities. However, it is 
unrealistic in the sense that it assumes that regional growth rates follow the national level within a few years in the forecast horizon. The third one is an intermediary assumption between the first and the second, since it uses past regional growth rates in the first part of the forecast horizon, later, when the future is more uncertain, it gives larger weights to the national rates. It assumes that on the long run, regional growth rates can be better approximated by the national average than on the basis of their own past values. It uses a weighting system, and assigns different weights to the past regional growth rates and to the projected national growth rate throughout the projection period (with a slight modification to those applied by Batista e Silva et al., 2016).

Table 4 The weighting system of Assumption 3)

\begin{tabular}{lcc}
\hline $\begin{array}{l}\text { projection } \\
\text { period }\end{array}$ & $\begin{array}{c}\text { weights assigned to the } \\
\text { national growth rate } \\
\left(w_{H U}\right)\end{array}$ & $\begin{array}{c}\text { weights assigned to past } \\
\text { regional growth rates } \\
\left(w_{\text {reg }}\right)\end{array}$ \\
\hline $2015-20$ & 0.0 & 1.0 \\
$2020-25$ & 0.2 & 0.8 \\
$2025-30$ & 0.4 & 0.6 \\
$2030-35$ & 0.6 & 0.4 \\
$2035-40$ & 0.8 & 0.2 \\
$2045-50$ & 1.0 & 0.0 \\
\hline
\end{tabular}

At this point, we arrived to the question of the proportional rescaling. Batista e Silva et al. (2016) proposes an ex post proportional rescaling to ensure that the sum of the projected regional GDP values matches the total national value of the reference projection. When using this technique, the national GDP evolves according to the reference projection and remains the same no matter what kind of regional disaggregation assumption is used. Assumptions 1) to 4) can only influence the internal distribution of the projected regional GDP values. The proportional rescaling is carried out according to the following equation:

$$
Y_{i, t+n}=Y_{H U, t+n} \cdot \frac{Y_{i, t+n}^{\prime}}{\sum_{i=1}^{r} Y^{\prime}{ }_{i, t+n}}
$$

where $Y_{i, t+n}$ is the GDP of the $i^{\text {th }}$ region after rescaling in period $t+n, Y_{H U, t+n}$ is national GDP in period $t+n, Y^{\prime}{ }_{i, t+n}$ is region $i$ 's projected GDP in period $t+n$ before rescaling, $\sum_{i=1}^{r} Y^{\prime}{ }_{i, t+n}$ is the sum of regional GDP values in period $t+n$ before rescaling, $r$ is the number of regions $t=2016$ is the base year and $n$ is the number of years in the projection horizon. The ex-post rescaling was done after each period. 
Figure 1 Coefficients of variance according to Assumptions 1) to 4)*

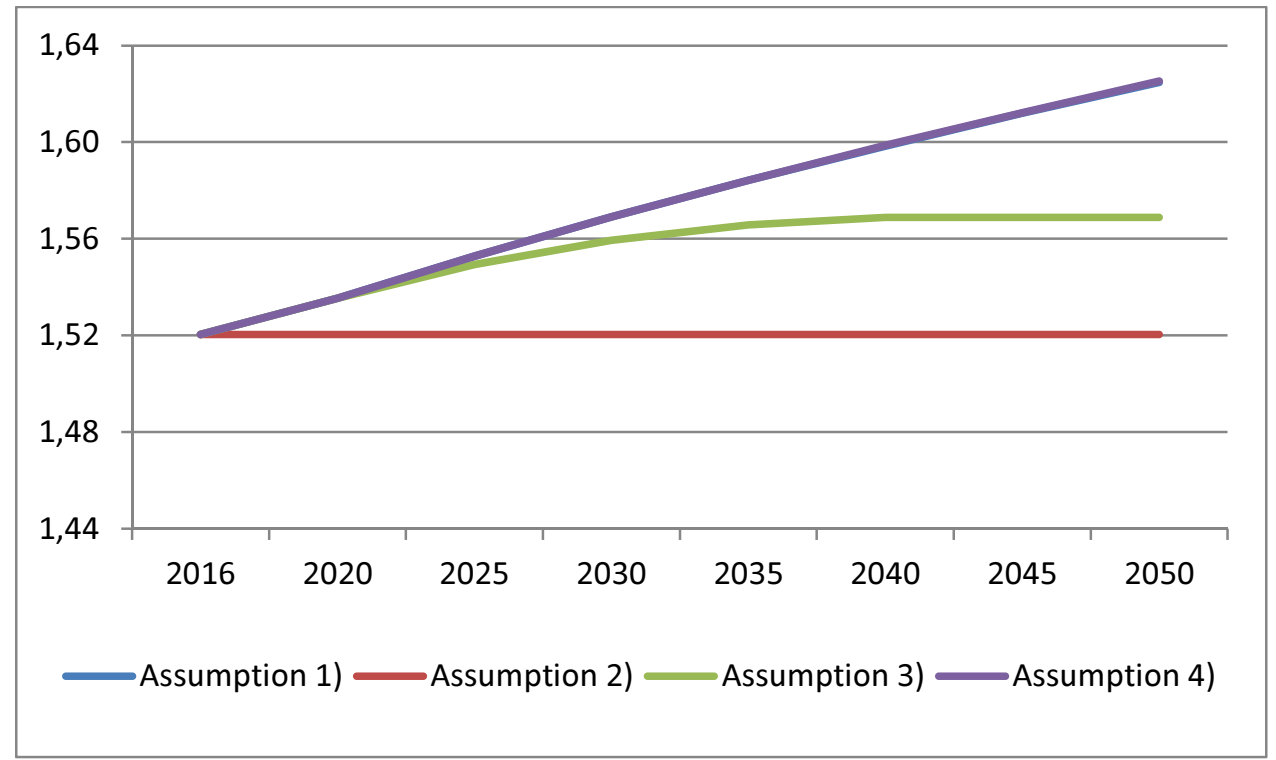

*Assumption 1) and 4) produced almost the same results

Source: own elaboration

The projected GDP values are presented in Tab. 10 in the Annex. Excepting Assumption 2), there are significant differences between the results if we use and do not use ex-post proportional rescaling with respect to the GDP levels, however, the spatial structure is unaffected. Nationally, the highest GDP is projected by Assumption 1) (without rescaling), while the results provided by Assumptions 3) and 4) (without rescaling) are not that much above those of Assumption 2). Unless we assume constant spatial inequalities (Assumption 2), all methods project increasing regional differences. Assumptions 1) and 4) deliver the least beneficial GDP projections for the less developed NUTS 3 regions and, at the same time, the highest GDP growth for the developed areas.

\section{Projections with GDP-decomposition}

Regional downscaling is done on the basis of the following decomposition of the per capita GDP (Szabó, 2015, Lengyel and Varga, 2018):

$\frac{G D P}{\text { population }}=\frac{G D P}{\text { employed persons }} \cdot \frac{\text { employed persons }}{\text { working age population }} \cdot \frac{\text { working age population }}{\text { population }}$

that is,

per capita $G D P=$

labour productivity $\cdot$ employment rate $\cdot$ rate of working age population

from which, we get the GDP as

$G D P=$

population $\cdot$ labour productivity $\cdot$ employment rate $\cdot$

rate of working age population 
Projections of population and the rate of working-age population at the NUTS 3 level are available from external sources (Lennert, 2018a). In this exercise, we prepare projections for labour productivity and employment rate through decomposing the national-level projections of the respective variables in the AR 2015. The projections will be made in the following four steps:

Step 1) use the results of Lennert (2018a) to get the NUTS 3 level projected population and working-age population;

Step 2) downscale employment rate to the NUTS 3 level on the basis of the AR 2015 projections;

Step 3) downscale labour productivity to the NUTS 3 level on the basis of the AR 2015;

Step 4) insert the four above factors to the equation of the GDP to get the NUTS 3 level projections.

\section{Demography}

Lennert (2018a) provided demographic projections at the district level (called ,járás“, LAU 1). The data are collected from HCSO (Demographic Yearbook and population census) and available on a 5 years $^{6}$ interval between 2016 and $2051^{19}$ according to nine different scenarios. The methodology ${ }^{20}$ relied on a cohort component model in which the basic factors of natural population change (birth rates and death rates) were applied on the different age cohorts (Tagai, 2015). The modelling of the internal migration extends the cohort component model with a behavioural approach in which the changes of residence are classified with respect to the place of origin, the place of destination, the demographic and socio-economic characteristics and the motivation of the people who move from one place to another. The nine scenarios were defined in terms of two dimensions, one considering natural population change (lower, baseline and higher) and one considering socio-economic policy (national competitiveness-oriented, baseline and territorial equity-oriented policies). We will consider only the baseline scenarios (Tab. 5), but, unfortunately, all of its scenarios projected constant population decline in Hungary (from 9.8 million in 2016 to between 8.4 million and 9.4 million in 2051 depending on the scenario) and decreasing rate of active population (from 66.2 percent in 2016 to between 52.6 and 55.7 percent in 2051 depending on the scenario). According to this projection, regional demographic inequalities will grow, since in three NUTS 3 regions (Fejér, Pest and Komárom-Esztergom) population is expected to increase or

\footnotetext{
${ }^{19}$ Our projections will run on a 5 years' interval from 2020 to 2050 , therefore, demographic projections are adjusted accordingly with a proportionate recalculation.

${ }^{20}$ See Lennert (2018b).
} 
remain stable, but in all other regions it will decrease with 11 to 28 percent. With respect to the rate of working-age population, regional inequalities are also expected to grow. In contrast, the AR 2015 is more optimistic about Hungarian demographic trends, since it projects a population of 9.3 million people in 2050 of which 58.1 percent belongs to the working-age population.

Table 5 Projected population (thousand people) and rate of active population (\%) at the NUTS 3 level in Hungary, 2016-51

\begin{tabular}{lrrr|rrr}
\hline & \multicolumn{3}{c|}{} & \multicolumn{3}{c}{$\begin{array}{c}\text { Rate of working-age } \\
\text { population }\end{array}$} \\
\cline { 2 - 7 } & 2016 & 2026 & 2051 & 2016 & 2026 & 2051 \\
\hline Bács-Kiskun & 504.8 & 470.6 & 374.5 & 65.1 & 59.8 & 50.8 \\
Baranya & 382.2 & 372.3 & 331.3 & 66.6 & 61.0 & 54.0 \\
Békés & 345.0 & 316.5 & 247.1 & 65.0 & 59.4 & 50.8 \\
Borsod-Abaúj-Zemplén & 676.3 & 654.3 & 570.3 & 65.4 & 59.8 & 52.4 \\
Budapest & 1727.3 & 1689.0 & 1540.0 & 66.2 & 62.8 & 56.8 \\
Csongrád & 411.4 & 397.4 & 349.5 & 66.5 & 61.8 & 54.6 \\
Fejér & 435.1 & 448.2 & 449.8 & 67.5 & 64.0 & 55.0 \\
Győr-Moson-Sopron & 445.0 & 433.5 & 385.1 & 67.0 & 63.0 & 53.1 \\
Hajdú-Bihar & 542.1 & 531.4 & 470.5 & 67.5 & 62.2 & 55.6 \\
Heves & 305.5 & 296.7 & 261.0 & 64.6 & 59.3 & 51.5 \\
Jász-Nagykun-Szolnok & 374.8 & 349.8 & 280.6 & 65.0 & 59.9 & 52.3 \\
Komárom-Esztergom & 309.7 & 314.8 & 307.2 & 66.5 & 62.7 & 53.5 \\
Nógrád & 198.9 & 190.5 & 159.8 & 64.2 & 56.6 & 44.9 \\
Pest & 1278.8 & 1381.8 & 1528.6 & 66.7 & 66.2 & 56.7 \\
Somogy & 307.7 & 289.3 & 235.0 & 65.1 & 58.2 & 48.5 \\
Szabolcs-Szatmár-Bereg & 547.9 & 523.3 & 437.0 & 67.4 & 62.0 & 53.1 \\
Tolna & 224.1 & 209.6 & 164.1 & 65.5 & 59.1 & 50.6 \\
Vas & 251.3 & 239.5 & 202.9 & 66.6 & 61.0 & 50.2 \\
Veszprém & 353.2 & 350.6 & 313.6 & 65.6 & 58.5 & 47.8 \\
Zala & 275.7 & 259.6 & 210.0 & 65.6 & 58.5 & 47.4 \\
\hline Hungary & 9896.8 & 9718.5 & 8818.1 & 66.2 & 61.8 & 53.7 \\
\hline
\end{tabular}

Source: own elaboration based on the data of Lennert (2018a)

\section{Employment rate projection}

In Step 2) of the projection we downscale the projected AR 2015 national-level employment rate with respect to the population aged 15 to 64 years. The European Commission (2015) publishes employment rate projections directly, in terms of percentages (not only total population data and the number of employees from which one could otherwise calculate employment rate indirectly). In AR 2015, employment is a residual variable, determined 
given Eurostat's population projections, future participation rates derived using a simulation model, and the unemployment rate assumptions.

Table 6 National-level projected employment rates of the 15 to 64 years old population in Hungary and in the EU-28, \%

Source: own elaboration based on European Commission (2015)

\begin{tabular}{cccccccc}
\hline & 2020 & 2025 & 2030 & 2035 & 2040 & 2045 & 2050 \\
\hline Hungary & 65.71 & 68.18 & 68.55 & 68.31 & 67.82 & 67.82 & 67.81 \\
EU-28 & 66.83 & 67.69 & 68.3 & 68.96 & 69.58 & 69.72 & 69.74 \\
\hline own elaboration based on European Commission (2015)
\end{tabular}

According to the AR 2015 projections, a constant catching-up is expected until 2030 in employment rates, but after it, Hungarian rates remain apparently below the EU-28 average.

The projections presented in Tab. 6 will be downscaled on the basis of past NUTS 3 level data of the period 2000 to 2015 provided by the Central Statistical Office of Hungary (HCSO). These series indicate that changes in the regional and county level employment rates rather well follow the changes in the national trends, furthermore, there is a clearly visible convergence: the cross-sectional standard deviation between the NUTS 3 regions decreased from 5.07 percentage points in 2000 to 4.02 percentage points in 2015.

Figure 2 Employment rates of the population aged 15 to 64 years, 2000-15 at the NUTS 3 level: lowest, highest and average Hungarian rates

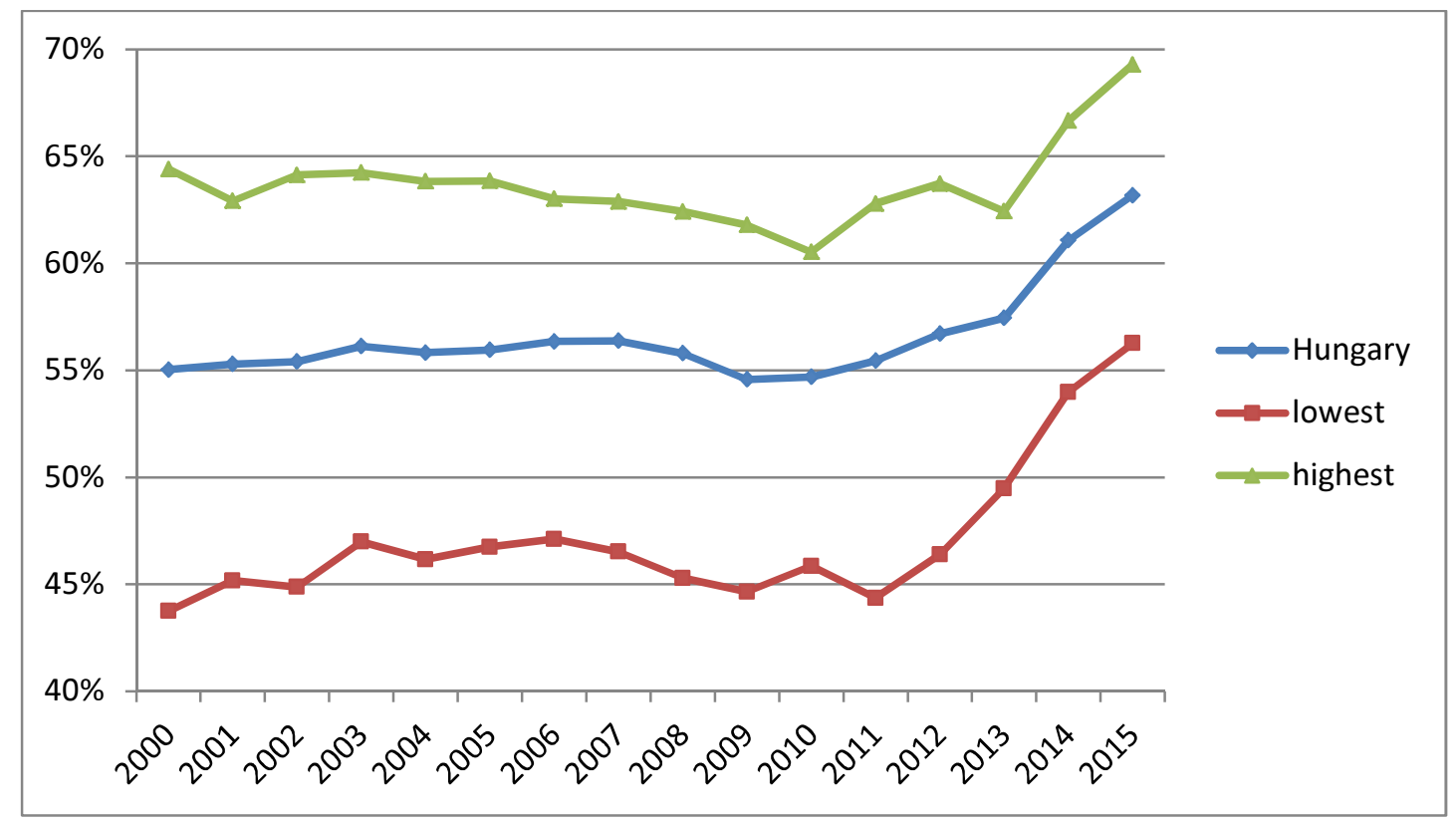

Source: own elaboration based on HCSO data

Regional employment rate data reveal a tendency according to which in those regions where the employment rate is above the national average, the deviation from the national average tends to gradually decrease and vice versa. In the long run, the convergence process is 
likely not sustainable, and in the past years it was driven mostly by national policy interventions. According to the beta convergence hypothesis, in those regions where the initial employment rate is lower, the growth rate of the employment rate should be higher and vice versa. This hypothesis is usually tested with the help of a regression. In our regression, the explanatory variable is the employment rate in $2000\left(\mathrm{emp}_{t}\right)$ (in logarithm) and the dependent variable is the annual growth rate of the employment rate between 2000 and 2015 (the lefthand side of the equation). Here, $t$ indicates the initial period, $n$ is the number of years, $\ln$ is natural $\operatorname{logarithm}, \alpha$ and $\beta$ are regression parameters and $\varepsilon$ is a random effect with zero mean.

$1 / n \ln \left(\frac{e m p_{t+n}}{e m p_{t}}\right)=\alpha+\beta \cdot \ln \left(e m p_{t}\right)+\varepsilon_{t+n}$

The output of the Ordinary Least Squares (OLS) ${ }^{21}$ estimation is a strongly significant, negative convergence parameter $\left(\beta=-0.0274, p=0.000, R^{2}=0.59\right)$. According to the results, regional differentials converge towards zero and expected to disappear between 2050 and 2055.

Figure 3 The relationship describing the convergence of NUTS 3 level employment rates

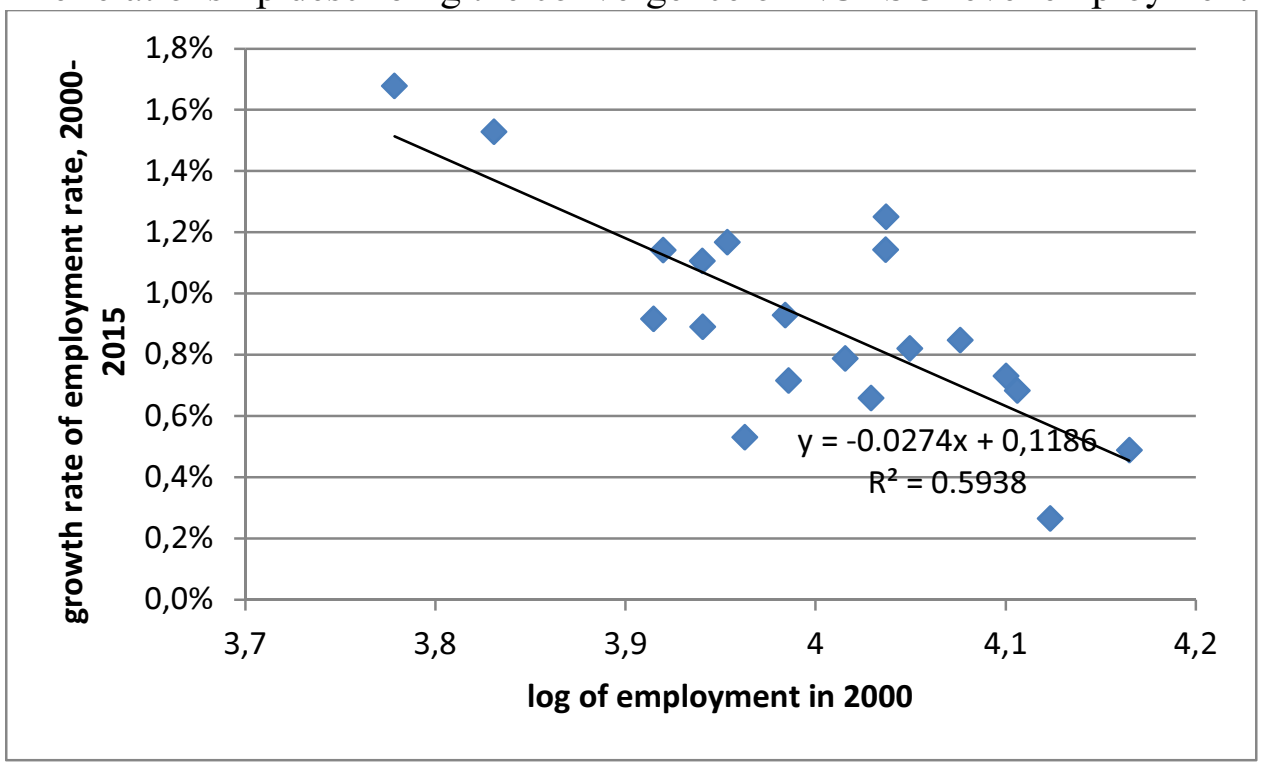

Source: own elaboration based on HCSO data

The convergence assumption is important from the point of view of our forecasting method, since if a significant relationship can be established between the initial position of a region and its growth rate, this relationship is applicable to project its long-run development path (e.g. in terms of employment). During the downscaling exercise we assume that the deviations of the regional level employment rates from the national level rates will converge

\footnotetext{
${ }^{21}$ OLS estimation has been chosen following the practice of Batista e Silva et al. (2016). In many cases, estimation methods that do not consider spatial autocorrelation are supposed to be biased. However, in our case, it is not easy to identify accurate spatial effects because of the relatively coarse spatial resolution of the data.
} 
to zero in the long run (convergence assumption). When we directly project employment rates on the basis of the beta convergence equation, the relationship will be linear for all regions. Instead, we only use this equation to compute the deviations of the NUTS 3 level employment rates from the national level employment rate. This means that the regional employment rates are linked to the national level forecasted rates, and national level projections are those presented by the AR 2015 (Tab. 6).

Table 7 Projected employment rates at the NUTS 3 level in Hungary, 2020-50, \%

\begin{tabular}{lrrrr}
\hline & 2020 & 2030 & 2040 & 2050 \\
\hline Bács-Kiskun & 62.4 & 67.6 & 67.9 & 67.7 \\
Baranya & 60.7 & 66.3 & 67.1 & 67.3 \\
Békés & 59.8 & 65.6 & 66.6 & 67.1 \\
Borsod-Abaúj-Zemplén & 58.0 & 64.1 & 65.6 & 66.7 \\
Budapest & 67.3 & 71.3 & 70.4 & 68.7 \\
Csongrád & 62.1 & 67.3 & 67.7 & 67.6 \\
Fejér & 68.4 & 72.1 & 70.9 & 68.9 \\
Győr-Moson-Sopron & 67.3 & 71.3 & 70.3 & 68.7 \\
Hajdú-Bihar & 57.5 & 63.8 & 65.4 & 66.6 \\
Heves & 59.9 & 65.7 & 66.6 & 67.1 \\
Jász-Nagykun-Szolnok & 62.1 & 67.3 & 67.8 & 67.6 \\
Komárom-Esztergom & 67.2 & 71.3 & 70.3 & 68.7 \\
Nógrád & 58.8 & 64.8 & 66.1 & 66.9 \\
Pest & 64.9 & 69.5 & 69.2 & 68.2 \\
Somogy & 57.0 & 63.3 & 65.1 & 66.4 \\
Szabolcs-Szatmár-Bereg & 56.3 & 62.8 & 64.7 & 66.3 \\
Tolna & 61.8 & 67.1 & 67.6 & 67.5 \\
Vas & 69.3 & 72.8 & 71.3 & 69.1 \\
Veszprém & 66.9 & 71.0 & 70.2 & 68.6 \\
Zala & 64.3 & 69.0 & 68.9 & 68.1 \\
\hline Hungary & 63.2 & 68.2 & 68.3 & 67.8 \\
\hline
\end{tabular}

Source: own elaboration based on European Commission (2015) and HCSO data

Note: Data are available on a 5 years' interval upon request.

\section{Labour productivity projections}

In Step 3) of our projection exercise we downscale the national level labour productivity projections provided by the AR 2015 to the NUTS 3 level which makes our GDP equation complete and allows us to compute projected GDP values.

Regional downscaling of labour productivity is also feasible with the help of convergence equations, analogously to the process applied in the case of employment rates (see e.g. Riahi et al., 2005 for GDP growth). The hypothesis of beta convergence can be tested with the following equation (Batista e Silva et al., 2016):

$1 / n \ln \left(\frac{\operatorname{prod}_{t+n}}{\operatorname{prod}_{t}}\right)=\alpha+\beta \cdot \ln \left(\operatorname{prod}_{t}\right)+\varepsilon_{t+n}$ 
where $\operatorname{prod}_{t}$ is labour productivity in the base period, $\operatorname{prod}_{t^{+} n}$ is labour productivity in period $t+n$. $t$ denotes the initial period (2000), $n$ is the number of years and $l n$ is the natural logarithm. The left-hand side of the equation is the annual growth rate of productivity, $\alpha$ and $\beta$ are regression parameters, and $\varepsilon$ is the residual with zero mean.

Batista e Silva et al. (2016) used national-level productivity data to estimate the convergence equation and found a strong, significant relationship, i.e. convergence between nations. However, this relationship may not apply for regions within countries, especially, when within country divergence is detected. When applying the beta convergence test for Hungarian NUTS 3 regions with respect to productivity, no significant relationship was revealed. Instead of using national data, we tested beta-convergence on the productivity data of Central and Eastern European NUTS 2 regions and found a significantly negative beta parameter $\left(\beta=-0.0292, p=0.0000, R^{2}=0.4771\right)$. Unfortunately, these parameters predicted full regional convergence until the year 2035 which is far from being realistic. For this reason, we opted not to use convergence function in the projection, but to employ the same procedure as described in the benchmark scenarios of GDP projection, according to Assumption 3) (see Tab. 4). The calculations use the AR 2015 national-level productivity growht projections (Fig. 4) and the NUTS 3 level past productivity growth rates, which are available between 2001 and 2015 (Tab. 8).

Figure 4 Projected growth rates of potential GDP per worker in Hungary and in EU-28, \%

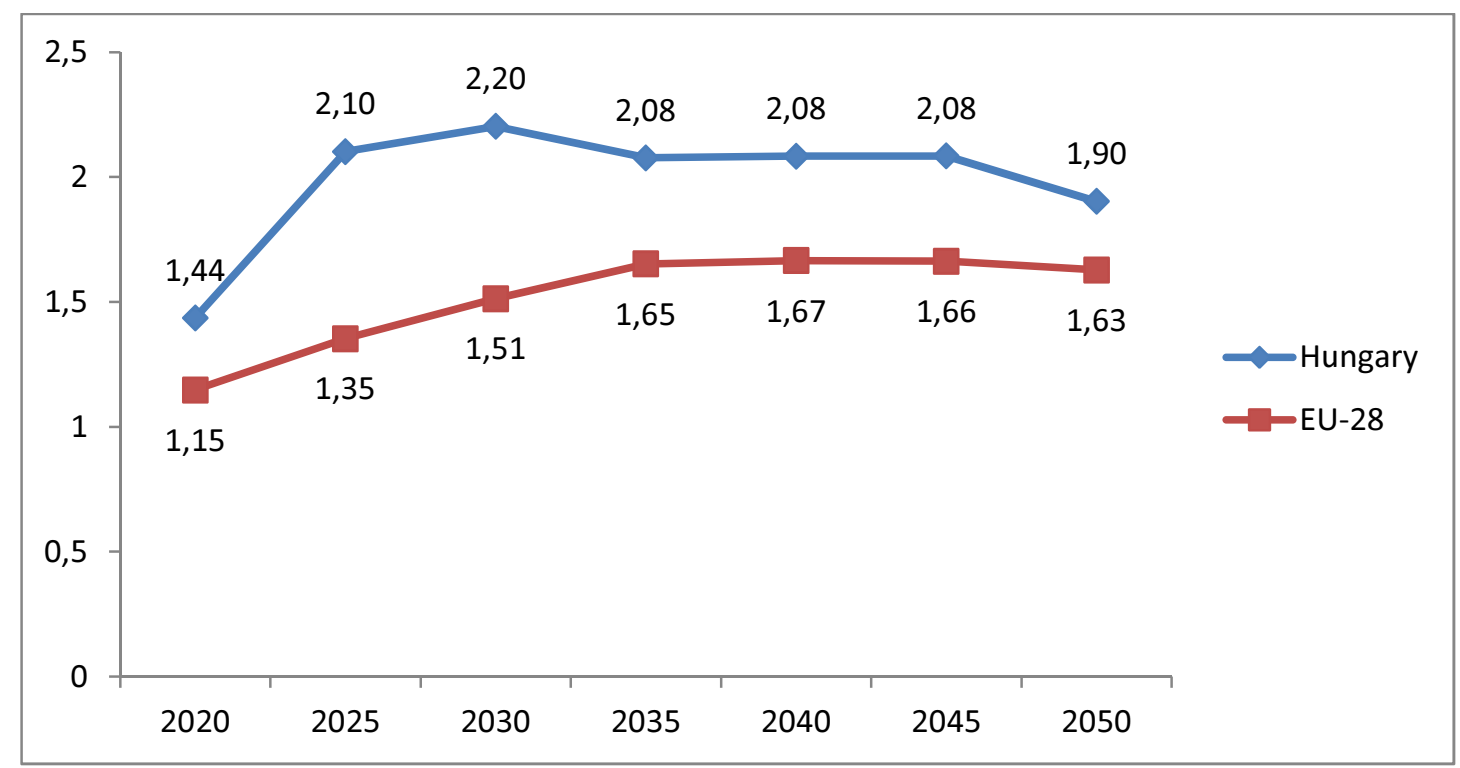

Source: own elaboration based on European Commission (2015) 
Table 8 Average growth rate of GDP per worker in Hungary at the NUTS 3 level, 2001-2015

\begin{tabular}{lr|lr}
\hline NUTS 3 region & $\begin{array}{l}\text { productivity } \\
\text { growth }\end{array}$ & NUTS 3 region & $\begin{array}{l}\text { productivity } \\
\text { growth }\end{array}$ \\
\hline Bács-Kiskun & 2.05 & Jász-Nagykun-Szolnok & 0.94 \\
Baranya & 0.25 & Komárom-Esztergom & 2.93 \\
Békés & 0.20 & Nógrád & -0.12 \\
Borsod-Abaúj-Zemplén & 1.48 & Pest & 2.27 \\
Budapest & 1.84 & Somogy & 1.08 \\
Csongrád & 1.11 & Szabolcs-Szatmár-Bereg & 0.05 \\
Fejér & 0.47 & Tolna & 0.83 \\
Györ-Moson-Sopron & 1.92 & Vas & 1.02 \\
Hajdú-Bihar & 1.15 & Veszprém & 0.70 \\
Heves & 1.71 & Zala & 1.86 \\
\hline Hungary & 1.44 & \multicolumn{2}{c}{} \\
Source: own elaboration based on HCSO and NBH (2015) &
\end{tabular}

Alternatively, we could assign a reasonable convergence year in an ad hoc way, which would lead to somewhat similar results. In the case of labour productivity projection, no ex post proportional rescaling was applied. As a result of our weighting system, the regional growth rates of labour productivity are assumed to fully converge until 2050 , however, this does not mean the full convergence of productivity levels, the cross-sectional variation coefficient is projected to rise from 35.2 percent in 2015 to 42.8 percent in 2040 and stabilize thereafter.

Table 9 Projected labour productivity (in constant 2005 prices) in Hungary

\begin{tabular}{lr|rccc}
\hline & 2015 & 2020 & 2030 & 2040 & 2050 \\
\hline & thousand HUF & \multicolumn{4}{|c}{$2015=100$} \\
\hline Bács-Kiskun & 4597 & 110.7 & 122.9 & 122.8 & 121.8 \\
Baranya & 3884 & 101.2 & 108.6 & 116.4 & 121.8 \\
Békés & 3731 & 101.0 & 108.2 & 116.2 & 121.8 \\
Borsod-Abaúj-Zemplén & 4580 & 107.6 & 118.2 & 120.7 & 121.8 \\
Budapest & 11268 & 109.5 & 121.2 & 122.0 & 121.8 \\
Csongrád & 4528 & 105.7 & 115.3 & 119.4 & 121.8 \\
Fejér & 5509 & 102.4 & 110.2 & 117.2 & 121.8 \\
Györ-Moson-Sopron & 7086 & 110.0 & 121.8 & 122.3 & 121.8 \\
Hajdú-Bihar & 4578 & 105.9 & 115.6 & 119.6 & 121.8 \\
Heves & 4492 & 108.8 & 120.1 & 121.5 & 121.8 \\
Jász-Nagykun-Szolnok & 3865 & 104.8 & 113.9 & 118.8 & 121.8 \\
Komárom-Esztergom & 5603 & 115.6 & 130.6 & 126.0 & 121.8 \\
Nógrád & 2760 & 99.4 & 105.8 & 115.2 & 121.8 \\
Pest & 4705 & 111.9 & 124.8 & 123.5 & 121.8 \\
Somogy & 3997 & 105.5 & 115.0 & 119.3 & 121.8 \\
Szabolcs-Szatmár-Bereg & 3561 & 100.2 & 107.0 & 115.7 & 121.8
\end{tabular}


Table 9 (continued)

\begin{tabular}{lr|cccc}
\hline & 2015 & 2020 & 2030 & 2040 & 2050 \\
\hline & thousand HUF & \multicolumn{4}{c}{$2015=100$} \\
\hline Tolna & 4427 & 104.2 & 113.0 & 118.4 & 121.8 \\
Vas & 5100 & 105.2 & 114.5 & 119.1 & 121.8 \\
Veszprém & 4072 & 103.6 & 112.0 & 118.0 & 121.8 \\
Zala & 4640 & 109.7 & 121.4 & 122.1 & 121.8 \\
\hline Hungary (weighted average) & 5876 & 107.4 & 123.7 & 122.9 & 121.8 \\
\hline
\end{tabular}

Source: own elaboration based on HCSO and NBH data

Note: Data are available on a 5 years' interval upon request.

\section{Results of the projection based on the decomposition of the per capita GDP}

Step 4) delivers the projections of GDP values for the NUTS 3 regions of Hungary between 2020 and 2050 at a 5 years $^{6}$ interval. Fig. 5 extends the series presented in Fig. 1 above with the results of the per capita GDP decomposition. This procedure projected the highest level of spatial variation between the GDP at the NUTS 3 level (see Tab. 11 in the Annex). In many cases (NUTS 3 regions) the decomposition method provided the lowest projected GDP values in comparison to the trend assumptions (1 to 4). An important factor behind these results is that our demographic projections, which have a central role in the decomposition-based projection, are more pessimistic than those of the AR 2015.

Figure 5 Coefficients of variation according to five different projection methods

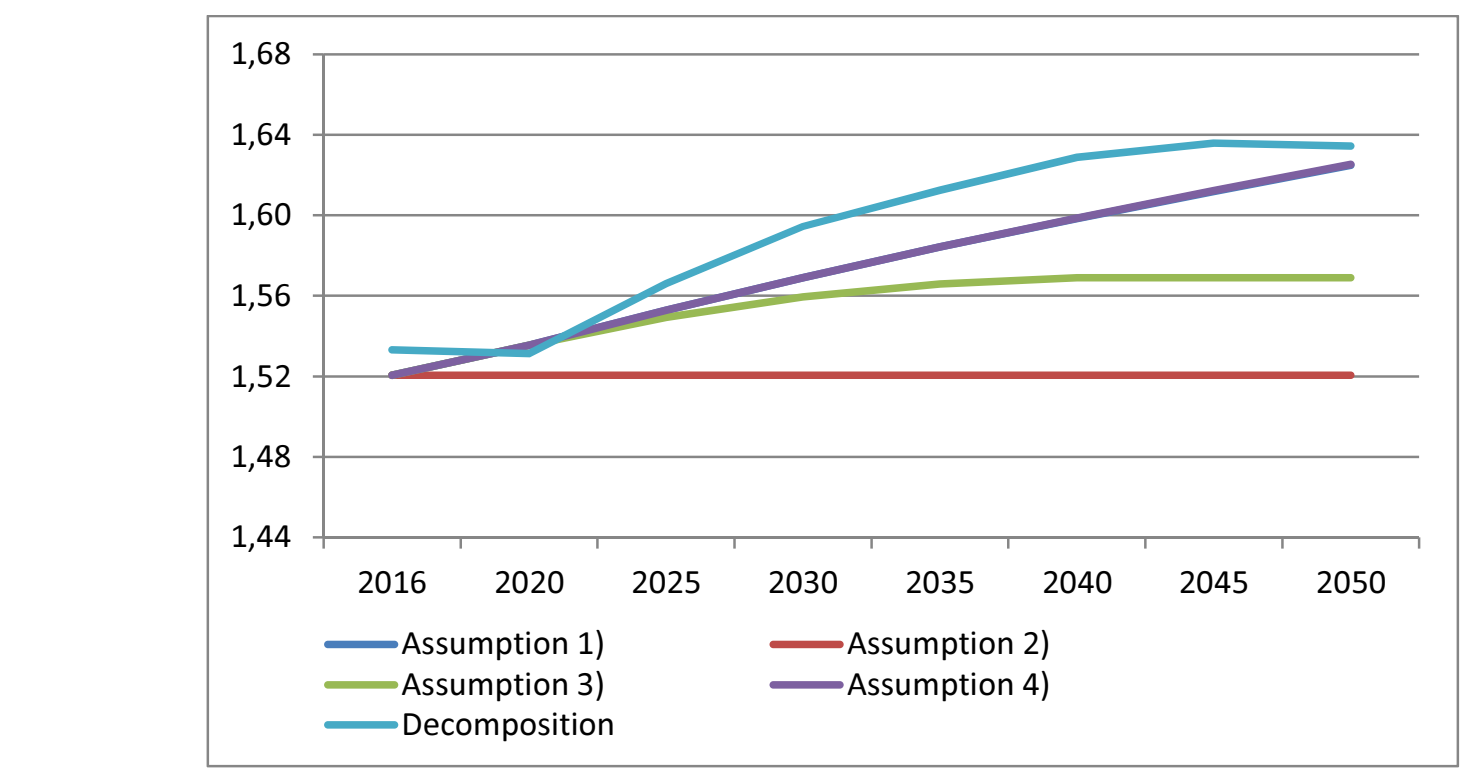

Source: own elaboration

Note: Assumption 1) and 4) delivered almost the same results.

\section{CONCLUSION}

In this paper we investigated the co-movement of regional-level and national-level economic (GDP) trends. The analysis of the theoretical and policy issues regarding regional inequalities 
allows us to conclude that both regional convergence and divergence are realistic scenarios, depending on the stance of policy-makers and the general national economic environment. Our aim was to apply some simplistic projection methods that may exhibit either regional convergence or divergence. The most simplistic trend approaches were used as benchmark and contrasted to a more sophisticated decomposition method. The results proved to be rather sensitive to the demographic changes, which is in compliance with the implications of the AR 2015. Excepting one method, all projection techniques indicated growing regional inequalities, which highlights the importance of regional policy from the point of view of social stability.

Of course, there remains ample room for improving our methodology. First, demographic variables and also the dynamics of employment should be endogenized. Interregional feedback mechanisms need to be integrated in the methodology, for example, in a system dynamics framework (see. e.g. Maani and Cavana, 2007) or a spatial econometric model. Multiple scenarios, e.g. policy scenarios can be elaborated in order to study the sensitivity of the system. In support of this, regional "convergence clubs" can be identified, like those of Lengyel and Varga (2018) or Iammarino et al. (2017). Finally, national-level forecast can be updated by using the Ageing Report 2018.

\section{Acknowledgement}

Project no. 120004 has been implemented with the support provided from the National Research, Development and Innovation Fund of Hungary, financed under the K_16 funding scheme.

\section{REFERENCES}

Baltagi, B.H., Fingleton, B., \& Pirotte, A. (2014). Estimating and forecasting with a dynamic spatial panel data model. Oxford Bulletin of Economics and Statistics, 76(1), 112-138.

Barca, F., McCann, P., \& Rodríguez-Pose, A. (2012). The case for regional development intervention: place-based versus place-neutral approaches. Journal of Regional Science, 52(1), 134-152.

Batista e Silva, F., Dijkstra, L., Martinez, P.V., \& Lavalle, C. (2016). Regionalisation of demographic and economic projections. Trend and convergence scenarios from 2015 to 2060. JRC Science for Policy Report EUR 27924 EN; doi: 10.2788/458769

Beenstock M., \& Felsenstein, D. (2007). Spatial Vector Autoregressions. Spatial Economic Analysis, 2(2), 167-196.

Capello, R., Caragliu, A., \& Fratesi, U. (2017a). Advances in Regional Growth Forecasting Models: Conceptual Challenges and Methodological Responses. International Regional Science Review, 40(1), 3-11.

Capello, R., Caragliu, A., \& Fratesi, U. (2017b). Modeling Regional Growth between Competitiveness and Austerity Measures: The MASST3 Model. International Regional Science Review, 40(1), 38-74.

Chizzolini, B. (2008). National and Regional Econometric Models. In R. Capello, R. Camagni, B. Chizzolini, \& U. Fratesi (Eds.), Modelling Regional Scenarios for the Enlarged Europe (pp. 69-82). Berlin, Heidelberg: Springer-Verlag. 
Dixon, P.B., Parmenter, B.R., Sutton, J., \& Vincent, D.P. (1982). ORANI: A Multisectoral Model of the Australian Economy. Amsterdam: North Holland Publishing Company.

Egyed, I. (2016). From uniformity towards unequality in regional development policy: The case of France. Deturope, 8(3), 33-52.

Elhorst, J.P. (2009). Spatial panel data models. In M. Fischer, A. Getis (Eds.), Handbook of Applied Spatial Analysis (pp. 377-407). Berlin, Heidelberg: Springer.

Enyedi, Gy. (2010). Terület- és településfejlesztéssel kapcsolatos tudományos kutatások fó irányai és feladatai [The main directions and tasks of the scientific researches in relation to spatial and settlement development], Területi Statisztika 13 (50)(4), 398-405.

European Commission (2015). The 2015 Ageing Report. Economic and budgetary projections for the 28 EU Member States (2013-2060). European Economy 3/2015, Economic and Financial Affairs [Pdf] Retrieved from http://ec.europa.eu/economy_finance/publications/european_economy/2015/pdf/ee3_en. pdf

Fratesi, U. (2009). The regional economist with the crystal ball: a discussion of the possibility of long-term predictions at sub-national level. Italian Journal of Regional Science, 8(1), 91-97.

Gaffin, S.R., Rosenzweig, C.R., Xing, X., \& Yetman, G. (2004) Downscaling and Geo-spatial Gridding of Socio-Economic Projections from the IPCC Special Report on Emissions Scenarios (SRES), Global Environmental Change A, 14, 105-123.

Gardiner, B., Martin, R., \& Tyler, P. (2011). Does spatial agglomeration increase national growth? some evidence from Europe. Journal of Economic Geography, 11(6), 1-28.

Gill, I. (2010) Regional development policies: Place-based or people-centred? [Html]. Retrieved from http://voxeu.org/article/regional-development-policies-place-based-orpeople-centred

Glaeser, E. L. (2011). Triumph of the City: How Our Greatest Invention Makes us Richer, Smarter, Greener, Healthier and Happier. New York: Penguin.

Haddad, E. (2009). Interregional Computable General Equilibrium Models. In M. Sonis \& G. J. D. Hewings (Eds.), Tool Kits in Regional Science - Theory, Models, and Estimation. Berlin, Heidelberg: Springer-Verlag.

Hadjimichalis, C., \& Hudson, R. (2014). Contemporary Crisis Across Europe and the Crisis of Regional Development Theories. Regional Studies, 48(1), 208-218.

Hoorelbeke, D., Lohest, O., Bassilière, D., Bossier, F, Bracke, I., \& Caruso, F. (2007). HERMREG: A regionalisation model for Belgium [Pdf]. Retrieved from https://ecomod.net/sites/default/files/document-conference/ecomod2007/93.pdf

Iammarino, S., Rodríguez-Pose, A., \& Storper, M. (2017). Why regional development matters for Europe's economic future. Working Papers of the Directorate-General for Regional and Urban Policy, WP 07/2017. Brussels: European Commission.

Jakobi, Á. (2004). Kísérletek a hazai területi egyenlőtlenségek előrejelzésére [Some experiments to forecast domestic spatial inequalities]. Regionális Tudományi Tanulmányok 9 (pp. 107-124). Budapest: ELTE Regionális Földrajzi Tanszék, MTAELTE Regionális Tudományi Kutatócsoport.

Keresztély, T. (2004) Előrejelzés és szcenárióelemzés hosszú távú makromodellel. [Forecasting and scenario analysis using a long-term macroeconomic model.] Statisztikai Szemle, 82(10-11), 919-944.

Koops, O., \& Muskens, J. (2005). REGINA: A model of economic growth prospects for Dutch regions. In F. van Oort, M. Thissen, \& L. van Wissen (Eds.), A survey of spatial economic planning models in the Netherlands. Theory, application and evaluation. Rotterdam: NAi Publishers, Netherlands Institute for Spatial Research, Den Haag.

Lehmann, R., \& Wohlrabe, K. (2014). Regional economic forecasting: stat-of-the-art methodology and future challenges. Economics and Business Letters, 3(4), 218-231. 
Lengyel, I., \& Kotosz, B. (2018). Felzárkózás és/vagy távolságtartó követés? A visegrádi országok térségeinek fejlődéséről. [Catching up and/or following at a distance? On the prospect of the regions of the Visegrad countries] Tér és Társadalom, 32(1), 5-26.

Lengyel, I., \& Varga, A. (2018). A magyar gazdasági növekedés térbeli korlátai - helyzetkép és alapvető dilemmák. [Spatial constraints of Hungarian economic growth - state of play and basic dilemmas] Közgazdasági Szemle, LXV., May, 499-524.

Lennert, J., Csatári, B., Farkas, J. Z., Mezőszentgyörgyi, D. (2015). Locality-based and placebased development in theory and practice - an example of the Hungarian countryside. Deturope, 7(2), 14-27.

Lennert, J. (2018a). Területi jövöképek - demográfia. [Spatial visions - Demography] Manuscript

Lennert, J. (2018b). Will the last one out turn off the lights? - Demographic scenarios for the Hungarian rural areas. In J. Zapletalová, A. Vaishar, M. Stastná (Eds.), Eurorural '18: 6th Moravian Conference on Rural Research: European Countryside and its Perception. 49 p. Brno: Mendel University in Brno.

Leunig, T. (2008). The regeneration game is up. The Guardian [Html]. https://www.theguardian.com/commentisfree/2008/aug/13/regeneration.conservatives.

Maani, K.E., \& Cavana, R.Y. (2007). Systems Thinking, System Dynamics. Managing Change and Complexity. Rosedale: Pearson Education New Zealand.

Magnani, R., \& Valin, H. (2009). Different approaches to modelling regional issues. Italian Journal of Regional Science, 8(1), 99-105.

Martin, R. (2008). National growth versus spatial equality? A cautionary note on the new 'trade-off' thinking in regional policy discourse. Regional Science Policy \& Practice, $1(1), 3-13$.

Martin, R. (2011). Regional economic resilience, hysteresis and recessionary shocks. Journal of Economic Geography, 12(1), 1-32.

Martin, R. (2015). Rebalancing the Spatial Economy: The Challenge for Regional Theory. Territory, Politics, Governance, 3(3), 235-272.

Mayor, M., López, A. J., \& Pérez, R.(2007). Forecasting regional employment with shiftshare and ARIMA modelling. Regional Studies, 41(4), 543-551.

McCann, P. (2016). The UK Regional-National Economic Problem: Geography, globalisation and governance. London, New York: Routledge.

OECD (2011). OECD Regional Outlook 2011: Building Resilient Regions for Stronger Economies. Paris: OECD Publishing. https://doi.org/10.1787/9789264120983-en.

Owyang, M.T., Rapach, D.E., \& Wall, H.J. (2009). States and the business cycle. Journal of Urban Economics, 65, 181-194.

Parmenter, B.R., \& Welsh, A. (2001). Historical simulations with the MONASH regional equation system. Australasian Journal of Regional Studies, 7(2), 209-230.

Ramajo, J., Márquez, M.A., \& Hewings, G.J.D. (2017). Spatiotemporal Analysis of Regional Systems: A Multiregional Spatial Vector Autoregressive Model for Spain. International Regional Science Review, 40(1), 75-96.

Riahi, K., Kolp, P., Grübler, A. (2005). National Scenarios of Economic Activity (GDP) - A Downscaling Analysis based on SRES. Interim Report IR-05-063. Laxenburg: International Institute for Applied Systems Analysis.

Stock, J.H., \& Watson, M.W. (2002). Macroeconomic forecasting using diffusion indexes. Journal of Business and Economic Statistics, 20, 147-162.

Szabó, P (2015). Régió és térszerkezet - az elmélettöl a területpolitikáig. [Region and spatial structure - From theory to spatial policy] Budapest: ELTE Eötvös Kiadó.

Tagai, G. (2015). Járási népesség-előreszámítás 2051-ig. [District-level population projection until 2051] In M. Czirfusz, E. Hoyk, A. Suvák (Eds.), Klímaváltozás - társadalom gazdaság: Hosszú távú területi folyamatok és trendek Magyarországon. [Climate change - society - economy. Long-run spatial processes and trends in Hungary] (pp. 141-166). Pécs: Publikon Kiadó. 
van Vuuren, D.P., Lucas, P.L., \& Hilderink, H. (2007). Downscaling drivers of global environmental change: Enabling use of global SRES scenarios at the national and grid levels. Global Environmental Change, 17, 114-130.

Varga, A. (2017). Place-based, Spatially Blind, or Both? Challenges in Estimating the Impacts of Modern Development Policies: The Case of the GMR Policy Impact Modeling Approach. International Regional Science Review, 40(1), 12-37.

Williamson, J.G. (1965). Regional inequality and the process of national development: a description of the patterns. Economic Development and Cultural Change, 13, 1-84.

World Bank (2009). World Development Report: Reshaping Economic Geography. Whashington, DC: World Bank.

Zsibók, Zs. (2017). Spatial imbalances in the United Kingdom after the Millennium: a focus on the cities. Deturope, 9(3), 61-84.

Zsibók, Zs., \& Sebestyén, T. (2017). Regionális gazdasági előrejelző modell, a klímaváltozás figyelembevételével. [Regional Economic Forecasting Model with Respect to the Climate Change] Területi Statisztika, 57(2), 132-159.

\section{ANNEX}

Table 10 The GDP in 2016 (in Hungarian forints, at constant, 2005 prices) and forecasted GDP (in percentage of the 2016 value) in 2050 according to Assumptions 1) to 4)

\begin{tabular}{|c|c|c|c|c|c|c|c|c|c|}
\hline & \multirow[t]{3}{*}{ GDP 2016} & \multicolumn{8}{|c|}{ GDP 2050} \\
\hline & & \multicolumn{2}{|c|}{ 1) } & \multicolumn{2}{|r|}{ 2) } & \multicolumn{2}{|r|}{ 3) } & \multicolumn{2}{|c|}{ 4) } \\
\hline & & $\begin{array}{c}\text { with } \\
\text { rescaling }\end{array}$ & $\begin{array}{l}\text { without } \\
\text { rescaling }\end{array}$ & $\begin{array}{c}\text { with } \\
\text { rescaling }\end{array}$ & $\begin{array}{l}\text { without } \\
\text { rescaling }\end{array}$ & $\begin{array}{c}\text { with } \\
\text { rescaling }\end{array}$ & $\begin{array}{l}\text { without } \\
\text { rescaling }\end{array}$ & $\begin{array}{c}\text { with } \\
\text { rescaling }\end{array}$ & $\begin{array}{l}\text { without } \\
\text { rescaling }\end{array}$ \\
\hline Bács-Kiskun & 990475 & 173.3 & 338.3 & 173.0 & 173.0 & 174.8 & 182.3 & 173.3 & 187.2 \\
\hline Baranya & 606796 & 100.5 & 104.4 & 173.0 & 173.0 & 139.7 & 145.7 & 100.3 & 108.4 \\
\hline Békés & 528883 & 96.0 & 202.7 & 173.0 & 173.0 & 137.1 & 142.9 & 95.7 & 103.4 \\
\hline Borsod-Abaúj-Zemplén & 1182702 & 164.5 & 307.5 & 173.0 & 173.0 & 171.0 & 178.4 & 164.4 & 177.6 \\
\hline Budapest & 9054783 & 172.6 & 126.8 & 173.0 & 173.0 & 174.5 & 181.9 & 172.5 & 186.4 \\
\hline Csongrád & 771765 & 121.9 & 164.0 & 173.0 & 173.0 & 151.2 & 157.7 & 121.7 & 131.5 \\
\hline Fejér & 1110515 & 140.6 & 500.1 & 173.0 & 173.0 & 160.4 & 167.2 & 140.5 & 151.8 \\
\hline Győr-Moson-Sopron & 1581713 & 225.7 & 731.6 & 173.0 & 173.0 & 194.9 & 203.3 & 226.0 & 244.1 \\
\hline Hajdú-Bihar & 953641 & 145.3 & 147.2 & 173.0 & 173.0 & 162.6 & 169.5 & 145.2 & 156.9 \\
\hline Heves & 548828 & 149.2 & 193.1 & 173.0 & 173.0 & 164.3 & 171.4 & 149.1 & 161.1 \\
\hline Jász-Nagykun-Szolnok & 624563 & 132.9 & 141.6 & 173.0 & 173.0 & 156.7 & 163.4 & 132.7 & 143.4 \\
\hline Komárom-Esztergom & 789709 & 270.9 & 208.4 & 173.0 & 173.0 & 210.2 & 219.2 & 271.4 & 293.2 \\
\hline Nógrád & 214081 & 77.5 & 113.0 & 173.0 & 173.0 & 125.5 & 130.9 & 77.2 & 83.4 \\
\hline Pest & 2551867 & 278.2 & 173.1 & 173.0 & 173.0 & 212.5 & 221.6 & 278.7 & 301.1 \\
\hline Somogy & 483455 & 113.5 & 143.4 & 173.0 & 173.0 & 146.8 & 153.1 & 113.3 & 122.4 \\
\hline Szabolcs-Szatmár-Bereg & 812920 & 150.7 & 251.5 & 173.0 & 173.0 & 165.0 & 172.1 & 150.6 & 162.7 \\
\hline Tolna & 418645 & 109.5 & 141.6 & 173.0 & 173.0 & 144.7 & 150.9 & 109.3 & 118.1 \\
\hline Vas & 639830 & 128.2 & 419.4 & 173.0 & 173.0 & 154.4 & 161.0 & 128.0 & 138.3 \\
\hline Veszprém & 662093 & 116.2 & 253.0 & 173.0 & 173.0 & 148.2 & 154.6 & 116.0 & 125.3 \\
\hline Zala & 528032 & 114.5 & 111.2 & 173.0 & 173.0 & 147.4 & 153.7 & 114.3 & 123.5 \\
\hline Hungary (total) & 25055296 & 173.0 & 225.5 & 173.0 & 173.0 & 173.0 & 180.4 & 173.0 & 186.9 \\
\hline
\end{tabular}


Table 11 Forecasted GDP, in percentage of the 2016 value, in 2050 according to the decomposition method (without ex post proportional rescaling)

\begin{tabular}{lr|lr}
\hline & GDP 2050 & & GDP 2050 \\
\hline Bács-Kiskun & 121.7 & Jász-Nagykun-Szolnok & 106.2 \\
Baranya & 120.7 & Komárom-Esztergom & 183.7 \\
Békés & 92.7 & Nógrád & 92.3 \\
Borsod-Abaúj-Zemplén & 146.1 & Pest & 228.0 \\
Budapest & 146.2 & Somogy & 112.0 \\
Csongrád & 134.4 & Szabolcs-Szatmár-Bereg & 103.7 \\
Fejér & 134.5 & Tolna & 101.1 \\
Győr-Moson-Sopron & 124.4 & Vas & 96.8 \\
Hajdú-Bihar & 151.0 & Veszprém & 104.7 \\
Heves & 143.9 & Zala & 117.5 \\
\hline Hungary (total) & 149.9 & & \\
\hline
\end{tabular}

Source: own elaboration 